\title{
Hibiskus (Hibiscus sabdariffa L.) Ekstraktı Tozu ile Soğuk Çay Üretimi: Antioksidan Aktivite ve Duyusal Özellikler
}

\author{
Abdullah Naji ${ }^{*}$, Serap Berktaş ${ }^{2}$, Mustafa Çam ${ }^{3}$ \\ 1*Erciyes Üniversitesi, Mühendislik Fakültesi, Gıda Mühendisliği, Kayseri, Türkiye, (ORCID: 0000-0002-8189-7563), nabdullahmohammed@gmail.com \\ 2 Erciyes Üniversitesi, Mühendislik Fakültesi, Gıda Mühendisliği, Kayseri, Türkiye (ORCID: 0000-0002-5195-0685), berktaserap@gmail.com \\ 3 Erciyes Üniversitesi, Mühendislik Fakültesi, Gıda Mühendisliği, Kayseri, Türkiye (ORCID: 0000-0003-1258-0834), mcam@erciyes.edu.tr
}

(Illk Geliş Tarihi 6 Eylül 2021 ve Kabul Tarihi 27 Aralık 2021)

(DOI: $10.31590 /$ ejosat.991763)

ATIF/REFERENCE: Naji, Abdullah., Berktaş, Serap. \& Çam, Mustafa (2021). Hibiskus (Hibiscus sabdariffa L.) Ekstraktı Tozu ile Soğuk Çay Üretimi: Antioksidan Aktivite ve Duyusal Özellikler. Avrupa Bilim ve Teknoloji Dergisi, (31), 831-836.

$\ddot{O} \mathbf{z}$

Hibiskus genellikle bitki çayı olarak tüketilen önemli biyolojik aktivitelere sahip bir bitkidir. Bu çalışmada, hibiskus ekstraktının püskürtmeli kurutucuda toz forma dönüştürülerek soğuk çay formülasyonlarında kullanılması ve üretilen soğuk çayların bazı fizikokimyasal ve duyusal özelliklerinin araştırılması amaçlanmıştı. Hibiskus bitkisi yapraklarından çalkalamalı su banyosu ile ekstrakt elde edilerek püskürtmeli kurutucuda maltodekstrin kullanılarak toz forma dönüştürülmüştür. Elde edilen toz forma dönüştürülmüşs hibiskus ekstraktı tozu (f) soğuk çay formülasyonları oluşturulmasında girdi olarak kullanılmıştır. Üretilen soğuk çayların renk, toplam asitlik, toplam fenolik madde, toplam flavonoid madde, antioksidan aktivite ve duyusal analizleri gerçekleştirilmiştir. Hibiskus soğuk çaylarının toplam fenolik madde miktarı 194,4-444,4 mg gallik asit eşdeğeri (GAE)/L olarak belirlenmiştir. Antioksidan kapasite iki farklı radikal ile belirlenmiş ve sonuçlar troloks eşdeğeri (TE) olarak verilmiştir. Bu değerler DPPH için 323,1-505,0 mg TE/L aralığında iken, ABTS için 303,2-665,6 mg TE/L olarak belirlenmiş̧ir. Toplam flavonoid madde miktarları da 399,4-844,8 mg kateşin eşdeğeri $(\mathrm{KE}) / \mathrm{L}$ bulunmuştur. Soğuk çay formülasyonları içerisinde kullanılan HET' nin \%0,25-0,50 ve sitrik asitin \%0,15-0,25 düzeylerinde kullanılmasının duyusal analiz sonuçlarında (renk, tat, aroma, bulanıklık ve genel beğeni) anlamlı bir farklılık oluşturmadığ1 belirlenmiştir $(\mathrm{p}>0,05)$.

Anahtar Kelimeler: Hibiscus sabdariffa L, soğuk çay, antioksidan, püskürtmeli kurutucu.

\section{Production of Iced Tea from Hibiscus (Hibiscus sabdariffa L.) Extract Powder: Antioxidant Activity and Sensory Properties}

\begin{abstract}
Hibiscus is a plant with important biological activities that are often consumed as herbal tea. In this study, it was aimed to microencapsulate hibiscus extract by a spray dryer, and to use the resulting microcapsules in iced tea formulations and to investigate some physicochemical and sensory properties of produced iced teas. The extract was obtained from the leaves of the hibiscus plant with a shaking water bath and microencapsulated using maltodextrin in a spray dryer. The obtained microencapsulated hibiscus extract powder (HET) was used as an input for the formation of iced tea formulations. Color, total acidity, total phenolic content, total flavonoid content, antioxidant capacity and sensory analyses of the produced iced teas were performed. The total phenolic content of hibiscus iced teas was determined as 194,4-444,4 mg gallic acid equivalent (GAE)/L. The antioxidant capacity was determined by two different radicals and the results were given as Trolox equivalents (TE). While these values were in the range of 323,1-505,0 mg TE/L for DPPH, it was determined as 303,2-665,6 mg TE/L for ABTS. Total flavonoid content was found to be 399,4-844,8 mg catechin equivalent $(\mathrm{KE}) / \mathrm{L}$. It was determined that the use of HET at $0,25-0,50 \%$ and citric acid at $0,15-0,25 \%$ levels used in iced tea formulations did not cause a significant difference in sensory analysis results (color, taste, aroma, turbidity and general acceptance) $(\mathrm{p}>0,05)$.
\end{abstract}

Keywords: Hibiscus sabdariffa L, iced tea, antioxidant, spray drying. 


\section{Giriş}

Hibiskus (Hibiscus sabdariffa L.) Malvaceae familyasındaki Hibiscus cinsine ait tek yıllık bir bitkidir. Afrika' ya özgü olan bu bitki, Amerika ve Güney Asya gibi tropikal ve subtropikal bölgelerde de yetiştirilmektedir (Moser ve ark., 2021). Hibiskus 300 ' den fazla türü olan ve çiçeklerinin renginden sorumlu olan antosiyaninler başta olmak üzere içerdiği fenolik bileşikler nedeniyle biyolojik öneme sahip bir bitkidir (Maciel ve ark., 2018). İçerdiği antosiyaninlerden özellikle delphinidin-3sambubioside ve siyanidin-3-sambubioside'in, hipertansiyon, iltihaplanma, karaciğer bozuklukları, diyabet ve metabolik sendroma karşı farmakolojik özelliklerinin olduğu tespit edilmiştir (Guardiola ve Mach, 2014).

Tüketicilerin beslenme alışkanlıklarının sağlıkları üzerinde önemli etkiler oluşturduğunun giderek farkına varmaları ile sağlığı koruyabilecek ürünlere olan talepleri de artmıştır. Çaylar ve bitkisel ürünler diyetimizde bulunan önemli biyoaktif bileşiklerin kaynaklarındandır. Çay, dünyanın birçok ülkesinde yaygın olarak tüketilen içecekler arasındadır. Çeşitli bitkilerden elde edilen çayların tüketimi, daha sağlıklı yaşam isteği ve münferit hastalıkların tedavisinde kullanılacak ilaç ihtiyacını azaltma ile de ilişkilidir. Bitkilere ait farklı fraksiyonların kaynatılması veya infüzyonu yoluyla bitkisel çayların hazırlanması geleneksel tıpta halen başvurulan yöntemlerdendir (Moser ve ark., 2021).

$\mathrm{Bu}$ amaçla yaygın olarak kullanılan bitkilerden biri olan hibiskustan elde edilen çayın özellikle hipertansiyon ve hiperlipidemi tedavisinde kullanıldığ 1 bildirilmektedir (Hopkins ve ark., 2013). Hibiskusun bu kullanım şekillerine ilave olarak kaliks kısımlarının işlenmesiyle reçel ve marmelat üretildiği ayrıca bitki çayı olarak tüketiminin yaygın olduğu rapor edilmiştir (Andzi Barhé ve Feuya Tchouya, 2016). Temel olarak benzer şekillerde üretilen hibiskus çayları direk tüketimine ilaveten jöleler, tatlılar, sıcak çay ve soğuk içecekler gibi çeşitli ürünlerin formülasyonlarına da girdiği görülmektedir (Nguyen ve Chuyen, 2020).

Soğuk çay yaygın olarak Camellia sinensis bitkisinden üretilmektedir ve alternatif olarak farklı bitkisel maddelerden üretilen soğuk çayların ürün çeşitliliği sınırlıdır. Hibiskus ekstraktları kullanılarak üretilen çeşitli ürünler literatürde rapor edilmişse de hibiskus ekstraktları kullanılarak soğuk çay üretimi ve karakterizasyonu üzerine daha önce yapılan herhangi bir çalışmaya rastlanılmamıştır. $\mathrm{Bu}$ nedenle, bu çalışmanın amacı HET kullanarak hibiskus soğuk çayı üretmek ve elde edilen soğuk çayların bazı fizikokimyasal ve duyusal özelliklerinin belirlenmesidir.

\section{Materyal ve Metot}

\subsection{Materyal ve Kimyasallar}

$\mathrm{Bu}$ çalışmada hibiskus bitkisi kurutulmuş formda yerel bir aktardan satın alınmıştır. Çalışmada kullanılan tüm kimyasallar ve standartlar Sigma-Aldrich ve Merck firmalarından temin edilmiştir.

\subsection{Hibiskus ekstraktlarının elde edilmesi ve ekstraktların püskürtmeli kurutulması}

Hibiskus ekstraktlarının elde edilmesinde çalkalamalı su banyosu yöntemi kullanılmıştır. 5 gram ögütülmüş hibiskus bitkisi $100 \mathrm{~mL}$ safsu ile $54^{\circ} \mathrm{C}$ " de 120 dakika boyunca $150 \mathrm{rpm}$ de çalkalamalı su banyosunda ekstrakte edilmiştir. Buradan elde edilen ekstraktlar maltodekstrin yardımlı püskürtmeli kurutma yöntemi ile toz forma dönüştürülmüştür (Naji, 2018). Elde edilen toz formdaki mikrokapsüller soğuk çay formülasyonlarında kullanılana kadar $4{ }^{\circ} \mathrm{C}$ ' de 1 şıksız ortamda muhafaza edilmiştir.

\subsection{Hibiskus soğuk çaylarının formülasyonu}

Hibiskus soğuk çaylarının formüle edilmesinde yapılan ön denemelerden sonra elde edilen duyusal sonuçlara göre Tablo 1' de verilen oranlara karar verilmiştir. Buna göre formülasyonda yer alan miktarlarda olacak şekilde sakaroz, sitrik asit ve HET ile soğuk çay içerikleri hazırlanmıştır. Daha sonra bu formülasyonlara göre hazırlanan dört farklı hibiskus soğuk çayı $250 \mathrm{~mL}$ ' lik önceden sterilize edilmiş cam şişelere doldurulup 80 ${ }^{\circ} \mathrm{C}^{\prime}$ de 10 dakika süre ile pastörize edilmiştir. Ardından hibiskus soğuk çayları analizler gerçekleştirene kadar $4{ }^{\circ} \mathrm{C}^{\prime} \quad \mathrm{de}$ depolanmıştır.

\section{Tablo 1. Hibiskus soğuk çaylarının formülasyonu}

\begin{tabular}{|l|l|l|l|}
\hline \multirow{2}{*}{ Örnekler } & \multicolumn{3}{|c|}{ Bileşenler (g) } \\
\hline $\mathbf{H}_{\mathbf{1}}$ & Sakaroz & Sitrik asit & HET \\
\hline $\mathbf{H}_{\mathbf{2}}$ & 7 & 0,15 & 0,25 \\
\hline $\mathbf{H}_{3}$ & 7 & 0,15 & 0,50 \\
\hline $\mathbf{H}_{4}$ & 7 & 0,25 & 0,25 \\
\hline
\end{tabular}

Tabloda verilen değerler $100 \mathrm{~mL}$ soğuk çaydaki miktarları ifade etmektedir.

\subsection{Renk, suda çözünür kuru madde, bulanıklık, pH ve titrasyon asitliği analizleri}

Hibiskus soğuk çaylarının L*, a* ve b* renk değeri ölçümleri kolorimetre cihazı (Konica Minolta, CR-5, Japonya) ile gerçekleştirilmiştir. Renk tayini yapılmadan önce cihazın siyah beyaz kalibrasyonu yapılmış ve $20 \mathrm{~mL}$ örnek ölçüm hücresine aktarılarak ölçümler gerçekleştirilmiştir. Suda çözünür kuru madde ( ${ }^{\circ}$ Briks) miktarını ölçmek için Abbe refraktometresinden (PAL-3, Tokyo, Japonya) faydalanılmıştır. Toplam kuru madde miktarının belirlenmesi için ise $20 \mathrm{~mL}$ örnek alınıp $70{ }^{\circ} \mathrm{C}$ de 24 saat etüvde (GEMO, DT104, Türkiye) kurumaya bırakılmıştır. Sonuçlar \% (m/m) olarak hesaplanmıştır. Bulanıklık türbidometre (Hach, ABD) cihazı kullanılarak ölçülüp sonuçlar Nefelometrik Bulanıklık Birimi (NTU) olarak ifade edilmiştir. Örneklerin $\mathrm{pH}$ değerleri bir pH metre (HANNA, ABD) cihazı kullanılarak ölçülmüştür. Titrasyon asitliği ise $0.1 \mathrm{~N}$ sodyum hidroksit ile titrimetrik olarak $\mathrm{pH}$ değerinin 8.1 olduğu değerde sarfiyatlar belirlenerek sonuçlar sitrik asitlik cinsinden hesaplanmıştır (Cemeroğlu, 2013). 


\subsection{Toplam fenolik madde miktarı}

Hibiskus soğuk çaylarının toplam fenolik madde miktarı Folin\&Ciocalteau reaktifi kullanılarak belirlenmiştir (Singleton ve Rossi, 1965). Örneklerden $0,4 \mathrm{~mL}$ deney tüpüne alınmış üzerine $2 \mathrm{~mL}$ Folin reaktifi $(1 / 10, \mathrm{v} / \mathrm{v}$, suda) ve 1,6 mL sodyum karbonat çözeltisi $(\% 7,5, \mathrm{w} / \mathrm{v})$ eklenerek vorteks (VWR, Almanya) ile karıştırılmıştır. Elde edilen örnek oda sıcaklığında karanlıkta 1 saat süre ile inkübe edilmiştir. Ardından spektrofotometre cihazı (UV-1800 Shimadzu, Japonya) ile 765 nm dalga boyunda örneklerin absorbansları ölçülmüştür. Kör çözelti olarak örnek yerine $0,4 \mathrm{~mL}$ saf su kullanılmıştır. Sonuçlar, gallik asit standartları ile elde edilen kalibrasyon grafiğinden hesaplanarak gallik asit eşdeğeri (GAE) olarak ifade edilmiştir.

\subsection{DPPH ile antioksidan kapasite}

Hibiskus soğuk çaylarının antioksidan kapasitesi Brand-Williams ve ark., (1995) metoduna göre 2,2-diphenyl-1-picrylhydrazyl (DPPH) radikali kullanılarak belirlenmiştir. Bunun için, 6,25 mg tartılan DPPH radikali $250 \mathrm{~mL}$ ' ye metanol $\mathrm{mL}$ ' ye metanol ile tamamlanmıştır. Elde edilen radikal çözeltisinden 3,9 mL alınarak $0,1 \mathrm{~mL}$ örnek ile karıştırılmış ve 30 dakika oda sıcaklığında karanlıkta inkübe edilmiştir. Kalibrasyon grafiklerinin oluşturulması amacıyla aynı işlem troloks çözeltileri (40-200 $\mathrm{mg} / \mathrm{L}$ ) ile tekrarlanmıştır. Kontrol örneği için ise örnek yerine 0,1 $\mathrm{mL}$ metanol kullanılmıştır. Daha sonra absorbanslar $515 \mathrm{~nm}$ dalga boyunda metanole karşı spektrofotometrede okunmuş ve sonuçlar troloks eşdeğeri (TE) cinsinden ifade edilmiştir.

\subsection{ABTS ile antioksidan kapasite}

Hibiskus soğuk çaylarının troloks eşdeğeri antioksidan kapasitesinin belirlenmesi için ABTS (2,2'-azino-bis-(3ethylbenzthiazoline-6-sulfonic acid)) yöntemi kullanılmıştır (Re ve ark., 1999; Bülent ve ark., 2020). ABTS radikal çözeltisinin hazırlanması için $5 \mathrm{~mL}$ potasyum persülfat çözeltisi $(12,25 \mathrm{mM})$ 0,192 g tartılmış olan ABTS radikali üzerine eklenerek $25 \mathrm{~mL}$ ' ye saf su ile tamamlanmıştır. Hazırlanan radikal çözelti 16 saat boyunca oda sıcaklığında karanlıkta bekletilmiştir. Ardından radikal stok çözeltisi, $734 \mathrm{~nm}$ ' de $0,700( \pm 0,02)$ absorbans değerine ulaşana kadar tuzlu fosfat tamponu $(\mathrm{pH} 7,4)$ ile seyreltilmiştir. Örneklerden $20 \mu \mathrm{l}$ alınarak üzerine $2 \mathrm{~mL}$ seyreltilmiş olan radikal çözeltisinden eklenerek 6 dakika oda sıcaklığında karanlıkta inkübe edilmiştir. Kalibrasyon grafiklerinin oluşturulması amacıyla aynı işlem troloks çözeltileri (0,2-1 mmol) ile tekrarlanmıştır. Kontrol örneği için ise $20 \mu \mathrm{l} \mathrm{saf}$ su kullanılmıştır. Örneklerin absorbansları $734 \mathrm{~nm}$ dalga boyunda spektrofotometrede ölçülmüştür. Sonuçlar, kalibrasyon grafiği yardımı ile troloks eşdeğeri (TE) olarak ifade edilmiştir.

\subsection{Toplam flavonoid madde miktarı}

Örneklerin toplam flavonoid madde miktarları Zhishen ve ark., (1999) yöntemine göre belirlenmiştir. Soğuk çay örneklerinden 1 $\mathrm{mL}$ alınıp üzerine $4 \mathrm{~mL}$ saf su ve $0,3 \mathrm{~mL} \mathrm{NaNO}_{2}$ çözeltisi $(\% 5$, $\mathrm{w} / \mathrm{v}$ ) ilave edilmiştir. 5 dakika inkübasyondan sonra $0.3 \mathrm{~mL} \mathrm{AlCl}$ çözeltisi (\%10, w/v) eklenmiş ve 1 dakika sonra da $2 \mathrm{~mL} \mathrm{NaOH}$ çözeltisi ( $1 \mathrm{~N}$ ) eklenmiştir. Son hacim 2,4 ml saf su ile $10 \mathrm{~mL}$ ' ye tamamlanmıştır. Kalibrasyon grafiklerinin oluşturulması amacıyla aynı işlem kateşin çözeltileri (10-120 mg/L) ile tekrarlanmıştır. Kör çözelti için ise örnek yerine $1 \mathrm{~mL}$ saf su kullanılmıştır. Hazırlanan örneklerinin absorbanları kör çözeltiye karş1 $510 \mathrm{~nm}$ dalga boyunda spektrofotometrede okunmuştur. Sonuçlar kalibrasyon grafiği yardımıyla kateşin eşdeğeri (KE) cinsinden ifade edilmiştir.

\subsection{Hibiskus soğuk çaylarının duyusal analizi}

Soğuk çaylar hazırladıktan sonra örneklerin duyusal analizi 20-45 yaşları arasında olan 14 eğitimli panelist tarafından gerçekleştirilmiştir. Örneklerin duyusal değerlendirmeleri 5 puanlı hedonik skala formu kullanılarak (1-hiç beğenmedim, 5çok beğendim) renk, aroma, tat, bulanıklık ve genel beğeni özellikleri açısından değerlendirilmiştir (Alaşalvar ve Çam, 2020).

\subsection{0. İstatistiksel analiz}

İki tekrarlı olarak yapılan soğuk çay üretimlerinden elde edilen analiz sonuçlarının karşılaştırmaları varyans analizini (ANOVA) takiben Tukey çoklu karşılaştırmaları testi kullanılarak SPSS 22 paket programı (SPSS Inc., Chicago, IL, USA) ile gerçekleştirilmiştir.

\section{Araştırma Sonuçları ve Tartışma}

\subsection{Hibiskus soğuk çaylarının fizikokimyasal özellikleri}

HET ile üretilen soğuk çayların renk, briks, $\mathrm{pH}$, bulanıklık, kuru madde ve titrasyon asitliği değerleri Tablo 2' de verilmiştir. Örneklerin L*, bulanıklık, $\mathrm{pH}$ ve kuru madde değerleri açısından aralarında istatistiksel olarak anlamlı bir farklılık bulunmamıştır $(\mathrm{p}>0,05)$. Titrasyon asitliği ve $\mathrm{b}^{*}$ değeri açısından en yüksek sonuçlara $\mathrm{H}_{4}$ kodlu örnekte ulaşılırken, en yüksek suda çözünür kuru madde değerleri $\mathrm{H}_{2}$ ve $\mathrm{H}_{4}$ kodlu örneklerde görülmüştür. $\mathrm{Bu}$ durum formülasyonlarda diğerlerine göre daha fazla kullanılan HET miktarı ile bağlantılı görünmektedir. Soğuk çay örneklerine eklenen sitrik asit miktarının artmasına bağlı olarak asitliğin arttığı, ancak pH değerinin sabit kaldığı görülmüştür $(2,86-3,02)$. $\mathrm{Bu}$ durum örneklerin tamponlama kapasitesi ile açıklanabilir. Örneklerde belirlenen bu düşük $\mathrm{pH}$ değerleri soğuk çay örneklerinin daha düşük sıcaklıkta ve daha kısa sürede pastörize edilmesine katkı sağlamaktadır (Karataşoğlu vd., 2021). Enginar, limon ve yeşil çayın farklı kombinasyonları ile üretilmiş soğuk çayların asitlik değerleri 1.16-1.24 olarak, Briks değerleri 5,607,55 olarak bildirilmiştir (Özünlü ve Ergezer, 2019). Adaçayı ve ıhlamur soğuk çaylarının $\mathrm{pH}$ değerleri sırasıyla 3,45 ve 3,05 olarak, L* değerleri ise sirasiyla 25,16 ve 23,70 olarak rapor edilmiştir (Alaşalvar ve Çam, 2019). Hibiskus soğuk çaylarının bileşiminde bulunan maddelerin miktarlarının değişmesi yukarıda belirtildiği gibi suda çözünür kuru madde ve titrasyon asitliğinde değişime neden olurken, bulanıklık değerlerinde anlamlı bir değişimine neden olmamıştır. Hibiskus soğuk çaylarının bulanıklık değerleri 5,27-7,76 NTU arasında olduğu ve istatistiksel olarak anlamlı bir fark olmadığı belirlenmiştir. Mikroenkapsüle nane ekstraktı tozlarının soğuk çay üretiminde kullanıldığı bir çalışmada ise örneklerin bulanıklık değerleri 204 NTU olarak belirlenmiştir (Alaşalvar ve Çam, 2020). Kombu çaylarının $\mathrm{pH}$ değerleri 3,18-3,19, toplam asitlik değerleri ise \%0,74-1,43 olarak rapor edilmiştir (Giritlioğlu vd., 2020). Hibiskus soğuk çaylarının a* değerleri 0,79-1,00 arasında tespit edilmiştir $(\mathrm{p}<0,05)$. Soğuk çaylar içerisindeki HET ve asitlik miktarı arttıkça kırmızılığın bir ölçüsü olan a* değerinin arttığı belirlenmiştir. Tıbbi ve aromatik nane türlerinden soğuk çayların 
üretildiği bir çalışmada ise çayların a* değerlerinin -0,85 ile 4,28 aralığında değişim gösterdiği belirtilmiştir (Alaşalvar \& Çam, 2020).

\subsection{Hibiskus soğuk çaylarının fenolik, flavonoid madde ve antioksidan kapasite değerleri}

Püskürtmeli kurutucuda maltodekstrin ile kaplanarak elde edilen HET ile üretilen soğuk çayların, toplam fenolik ve toplam flavonoid madde miktarları ile antioksidan kapasite değerleri Şekil 1 ve 2' de verilmiştir. Hibiskus soğuk çaylarının toplam fenolik madde miktarları 194,4-444,4 mg GAE/L arasinda değişmektedir. Soğuk çaylarda kullanılan HET miktarı ile toplam fenolik ve toplam flavonoid madde miktarlarının paralellik gösterdiği ve HET miktarı arttıkça değerlerin anlamlı şekilde arttığı $(\mathrm{p}<0,05)$ belirlenmiştir. İki farklı nane türünden elde edilen ekstraktlar ile üretilen soğuk çayların toplam fenolik madde miktarı 274-370 mg GAE/L olarak rapor edilirken (Alaşalvar ve Çam, 2020), rooibos ile üretilen soğuk çayların toplam fenolik madde içerikleri 338-509 mg GAE/L olarak rapor edilmiştir (Viljoen vd., 2017). Özünlü ve Ergezer (2019), enginar yaprakları ile ürettikleri soğuk çayların toplam fenolik madde içeriklerini 2808-2962 mg GAE/L olarak belirlemişlerdir. Bu durumun araştırmacıların soğuk çay hazırlarken kullandıkları ekstraktların cinsi ve miktarlarının fazla olması ile ilgili olduğu düşünülmektedir. Akarca ve Tomar, (2018) ise kombucha çaylarının toplam fenolik madde içeriklerini $7.8 \mathrm{mM}(1326 \mathrm{mg}$ GAE/L) olarak tespit etmişlerdir. Akarca ve Tomar, (2018) ve Özünlü ve Ergezer (2019) tarafından yapılan çalışmalarda toplam fenolik madde miktarının yüksek olmasının nedeni soğuk çay formülasyonlarında kullanılan ekstraktların miktarının daha yüksek olması ile ilişkili olduğu düşünülmektedir. Araştırmacılar kuru madde temelli ekstrakt miktarı vermedikleri için materyal bazlı anlamlı karşılaştırma yapılamamıştır

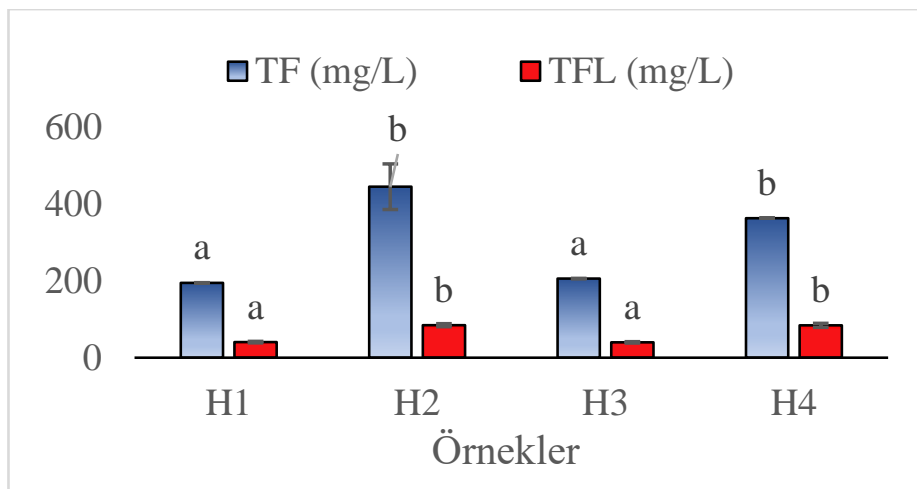

Şekil 1. Hibiskus soğuk çaylarının toplam fenolik (TF) ve toplam flavonoid (TFL) madde içerikleri

Şekil üzerinde verilen değerler 2 tekrarlı verilerin ortalama değerlerini, hata barları ise standart sapma değerlerini ifade etmektedir. Aynı barlar üzerindeki farklı harfler ortalamalar arasında istatistiksel olarak anlaml 1 farklılı̆ $\breve{g}_{1} \quad(p<0.05)$ göstermektedir.

HET ile üretilen soğuk çayların DPPH ve ABTS yöntemleri ile elde edilen antioksidan kapasite değerleri sirasıyla 323-505 mg TE/L ve 303-666 mg TE/L arasında değişim göstermiştir. DPPH ile yapılan antioksidan kapasite analizinde her ne kadar örnekler arasında HET miktarı farkı var ise de bu farkların antioksidan kapasiteye (DPPH) yansımadığı görülmektedir $(\mathrm{p}>0,05)$. Bunun aksine ABTS ile yapılan antioksidan kapasite analizinde örnekler içerisindeki HET miktarı farkının antioksidan kapasiteye yansıdığı ve örnekler arasında anlamlı farklar olduğu belirlenmiştir $(p<0,05)$. Bu durum ABTS radikalinin HET içerisindeki bileşenlere daha belirgin tepki verdiğinin işareti olarak görülebilir. 4 farklı formülasyonda üretilen soğuk çaylar arasında en yüksek antioksidan kapasiteyi (ABTS) $\mathrm{H}_{4}$ kodlu örnek göstermiştir. ABTS testinin örnekler içerisindeki ekstrakt miktarını yansıtmasına ilaveten sitrik asit miktarındaki farklılıklara dahi duyarlı olduğu görülmektedir. Moser ve ark., (2021) hibiskusun sıcak ve soğuk infüzyonlarının toplam fenolik madde değerlerini 3,74-4,55 mg GAE/g olarak, DPPH ve ABTS değerlerini ise 196-219 $\mu \mathrm{M}$ TE/g ve 45,10-85,68 $\mu \mathrm{M}$ TE/g olarak belirlemişlerdir. Nane ekstraktlı soğuk çayların antioksidan kapasiteleri (DPPH ile $\mathrm{EC}_{50}$ eş değeri olarak) 389-481 mg/g DPPH olarak rapor edilmiştir (Alaşalvar ve Çam, 2020).

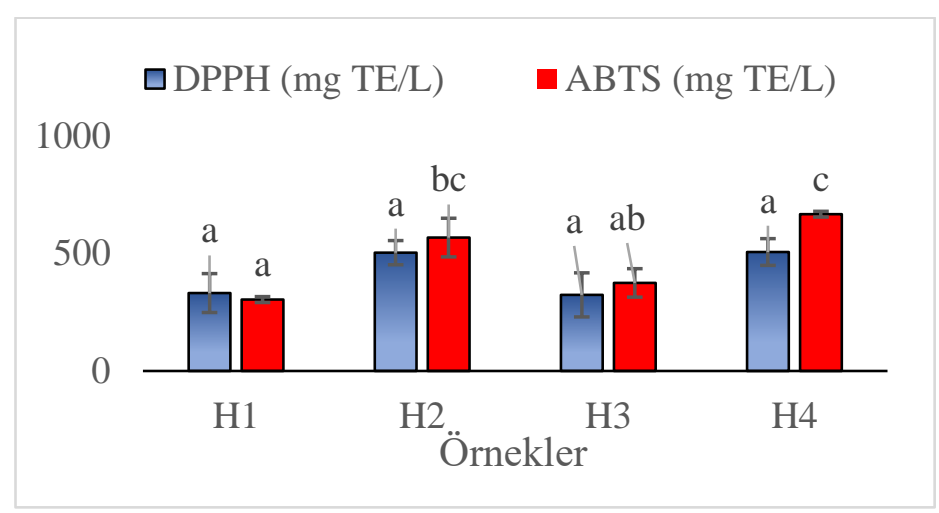

Şekil 2. Hibiskus soğuk çaylarının antioksidan kapasite değerleri

Şekil üzerinde verilen değerler 2 tekrarlı verilerin ortalama değerlerini, hata barları ise standart sapma değerlerini ifade etmektedir. Aynı barlar üzerindeki farklı harfler ortalamalar arasında istatistiksel olarak anlamlı farklılığı $(\mathrm{p}<0.05)$ göstermektedir

Aynı çalışmada nane soğuk çaylarının antioksidan kapasitesi (ABTS) 615-809 mg TE/L olarak rapor edilmiştir. Bu çalışma bizim çalışmamızla paralellik göstermekte olup kullanılan esktraktların cinsi farklı olsa da (nane ve hibiskus) benzer antioksidan kapasite sonuçlarına ulaşılmıştır. 
Tablo 2. Hibiskus soğuk çaylarına ait bazı fizikokimyasal özellikler

\begin{tabular}{|c|c|c|c|c|c|c|c|c|}
\hline Örnekler & $\mathbf{L}^{*}$ & $a^{*}$ & $\mathbf{b}^{*}$ & Briks (\%) & pH & $\begin{array}{l}\text { Titrasyon } \\
\text { asitliği (\% } \\
\text { sitrik asit) }\end{array}$ & $\begin{array}{l}\text { Bulanıklık } \\
\text { (NTU) }\end{array}$ & $\begin{array}{l}\text { Kuru } \\
\text { madde (\%) }\end{array}$ \\
\hline $\mathrm{H}_{1}$ & $24,04 \pm 1,92^{a}$ & $0,79 \pm 0,00^{a}$ & $1,02 \pm 0,16^{\mathrm{a}}$ & $7,6 \pm 0,00^{a}$ & $3,00 \pm 0,09^{\mathrm{a}}$ & $0,20 \pm 0,01^{\mathrm{a}}$ & $5,83 \pm 0,66^{\mathrm{a}}$ & $7,50 \pm 0,02^{a}$ \\
\hline $\mathbf{H}_{2}$ & $22,00 \pm 0,06^{\mathrm{a}}$ & $0,95 \pm 0,00^{b}$ & $\begin{array}{l}1,22 \pm 0,02 \\
\text { ab }\end{array}$ & $7,8 \pm 0,00^{b}$ & $3,02 \pm 0,04^{\mathrm{a}}$ & $0,27 \pm 0,01^{b}$ & $7,12 \pm 0,80^{a}$ & $7,73 \pm 0,16^{\mathrm{a}}$ \\
\hline $\mathrm{H}_{3}$ & $21,38 \pm 0,00^{\mathrm{a}}$ & $1,00 \pm 0,04^{b}$ & $\begin{array}{l}1,56 \pm 0,04 \\
\text { bc }\end{array}$ & $7,65 \pm 0,07^{a}$ & $2,86 \pm 0,01^{\mathrm{a}}$ & $0,31 \pm 0,00^{c}$ & $5,27 \pm 0,85^{a}$ & $7,69 \pm 0,09^{a}$ \\
\hline $\mathbf{H}_{4}$ & $22,19 \pm 1,39^{a}$ & $0,96 \pm 0,01^{b}$ & $1,64 \pm 0,01^{\mathrm{c}}$ & $7,8 \pm 0,00^{b}$ & $2,89 \pm 0,07^{\mathrm{a}}$ & $0,37 \pm 0,01^{\mathrm{d}}$ & $7,76 \pm 0,86^{\mathrm{a}}$ & $7,84 \pm 0,06^{\mathrm{a}}$ \\
\hline
\end{tabular}

\subsection{Hibiskus soğuk çaylarının duyusal özellikleri}

HET ile üretilen soğuk çayların duyusal analiz sonuçları Tablo 3' te verilmiştir. Hibiskus soğuk çayları arasında renk, tat, aroma, bulanıklık ve genel beğeni açısından istatistiksel olarak anlamlı bir farklılık bulunmamıştır ( $>>0,05)$. Hibiskus soğuk çaylarının formülasyonda kullanıldığı bileşenlerin oranının (sitrik asit ve HET) değiştirilmesiyle ürünler arasında anlamlı bir fark $(\mathrm{p}>0,05)$ gözlenmemiştir. Soğuk çay formülasyonlarında farklılıklar olmasına ve bu farklılıkların bazı enstrümantal ölçümler (asitlik, $a^{*}, b^{*}$ TF vb.) ile tespit edilmesine rağmen duyusal analizin herhangi bir parametresinde farklılık görülmemiştir. Tüm örneklerin aldığı duyusal skorlar bu 4 formülasyonun da kabul edilebilir düzeyde olduğuna işaret etmektedir. Nguyen ve Chuyen, (2020) $80{ }^{\circ} \mathrm{C}$ de kurutulan hibiskus bitkisinden elde edilen çayın duyusal değerlendirme sonuçlarının yüksek olduğunu bildirmişlerdir. Hibiskus, antosiyanin içeriğiyle ilişkili olarak karakteristik bir asit tadına sahiptir ve bu tat elde edilecek ürünlerin lezzetine etki etmektedir ( Preciado-Saldaña ve ark., 2019). Ancak elde edilen sonuçlara göre, farklı Oranlarda HET içeren çaylar arasında lezzet farklılığı görülmemiştir. Bu durum lezzet farklılığı oluşturabilecek miktarda HET kullanılmadığını göstermektedir. Buna neden olan yapılan ön denemeler neticesinde ekstrem koşullardaki formülasyonların elenmiş olmasıdır. Yeni bir ürün geliştirilirken elde edilecek ürünün fonksiyonel özellik sağlayacak nitelikte yüksek miktarda biyoaktif bileşik içermesi ve ürünün tekrarlanan tüketimini sağlayacak duyusal niteliklere sahip olması tercih edilmektedir. Geliştirilen hibiskus soğuk çaylarının hem biyoaktif özellikler sergilemesi hem de duyusal açıdan kabul edilebilir niteliğe sahip olması bu açıdan önemli bir yere sahiptir.

\section{Sonuç}

Hibiskus bitkisi önemli biyolojik aktivitelere sahip olan ve çeşitli gıda formülasyonlarında kullanım potansiyeli bulunan bir bitkidir. $\mathrm{Bu}$ çalışmada püskürtmeli kurutucuda toz forma dönüştürülmüş hibiskus ekstraktı tozu (HET) kullanılarak biyoaktif bileşiklerce zengin, içime hazır soğuk çay üretimi gerçekleştirilmiştir. Literatürde yer alan bazı çalışmalarda soğuk çayların konsantre ekstraktlardan üretildikleri görülmektedir. Bu çalışmada ise ekstraktların mikrobiyolojik ve depolama açısından daha güvenli bir formu olan HET ile üretim yapılması üretimde esneklik ve avantaj sağlamaktadır. Bitki çayı olarak da sıklıkla tüketilen hibiskus bitkisine soğuk çay gibi farklı ürünlerin bileşiminde de yer verilerek kullanım alanlarının artırılabileceği düşünülmektedir.

\section{Teșekkür}

$\mathrm{Bu}$ çalışma Erciyes Üniversitesi Bilimsel Araştırma Projeleri Birimi [proje no: FYL-2018-8029] tarafindan desteklenmiştir.

Tablo 3. Hibiskus soğuk çaylarının duyusal özellikleri

$\begin{array}{llllll}\text { Örnekler } & \text { Renk } & \text { Tat } & \text { Aroma } & \text { Bulanıklık } & \text { Genel beğeni } \\ \mathbf{H}_{1} & 3,75 \pm 1,22^{\mathrm{a}} & 4,00 \pm 1,04^{\mathrm{a}} & 3,36 \pm 1,39^{\mathrm{a}} & 4,29 \pm 0,91^{\mathrm{a}} & 3,86 \pm 1,03^{\mathrm{a}} \\ \mathbf{H}_{2} & 4,29 \pm 0,91^{\mathrm{a}} & 3,57 \pm 1,09^{\mathrm{a}} & 3,21 \pm 1,39^{\mathrm{a}} & 3,50 \pm 1,40^{\mathrm{a}} & 3,64 \pm 1,08^{\mathrm{a}} \\ \mathbf{H}_{3} & 3,68 \pm 1,30^{\mathrm{a}} & 3,43 \pm 1,40^{\mathrm{a}} & 3,21 \pm 1,42^{\mathrm{a}} & 4,29 \pm 1,20^{\mathrm{a}} & 3,57 \pm 1,16^{\mathrm{a}} \\ \mathbf{H}_{4} & 4,57 \pm 0,76^{\mathrm{a}} & 3,71 \pm 1,14^{\mathrm{a}} & 3,36 \pm 1,33^{\mathrm{a}} & 3,50 \pm 1,70^{\mathrm{a}} & 3,86 \pm 0,95^{\mathrm{a}}\end{array}$

Tablo üzerinde verilen değerler 2 tekrarlı verilerin ortalama \pm standart sapma değerlerini ifade etmektedir. Aynı sütundaki farklı harfler ortalamalar arasında istatistiksel olarak anlamlı farklılı̆ ${ }_{1}(\mathrm{p}<0,05)$ göstermektedir. 


\section{Kaynakça}

Akarca, G. ve Tomar, O. (2018). Siyah ve Yeşil Çay İle Üretilen Kombucha Çaylarının Antimikrobiyal ve Antioksidatif Özellikleri. Avrupa Bilim ve Teknoloji Dergisi, 14, 96-101.

Alaşalvar, H. ve Çam, M. (2019). Process for production of ready to drink iced teas from sage (Salvia officinalis L.) and linden (Tilia cordata): pressurized hot water extraction and spray drying. Food Science and Biotechnology, 28(3), 779-785.

Alaşalvar, H. ve Çam, M. (2020). Ready to drink iced teas from microencapsulated spearmint (Mentha spicata L.) and peppermint (Mentha piperita L.) extracts: physicochemical, bioactive and sensory characterization. Journal of Food Measurement and Characterization, 14(3), 1366-1375.

Andzi Barhé, T. ve Feuya Tchouya, G. R. (2016). Comparative study of the anti-oxidant activity of the total polyphenols extracted from Hibiscus Sabdariffa L., Glycine max L. Merr., yellow tea and red wine through reaction with DPPH free radicals. Arabian Journal of Chemistry, 9(1), 1-8.

Brand-Williams, W., Cuvelier, M. E. ve Berset, C. (1995). Use of a free radical method to evaluate antioxidant activity. LWT Food Science and Technology, 28(1), 25-30.

Bülent, B., Hamza, A., Nurcan, D., Cemhan, D., Serap, B., \& Mustafa, Ç. (2020). Wild mustard (Sinapis arvensis) parts: compositional analysis, antioxidant capacity and determination of individual phenolic fractions by LC-ESIMS/MS. Journal of Food Measurement \& Characterization, 14(3), 1671-1681.

Cemeroğlu, B. S., (2013). Gıda Analizleri, Ankara Üniversitesi Mühendislik Fakültesi, Ankara.

Preciado-Saldaña A, Abraham Domínguez-Avila J, Fernando Ayala-Zavala J, Villegas-Ochoa MA, Sáyago-Ayerdi SG, Wall-Medrano A, González-Córdova AF, González-Aguilar GA. (2019). Formulation and characterization of an optimized functional beverage from hibiscus (Hibiscus sabdariffa L.) and green tea (Camellia sinensis L.). Food Science and Technology International, 25(7), 547-561.

Giritlioğlu, N., Yıldız, E. ve Gürbüz, O. (2020). Kombu Çayı Üretiminde Kapari Tomurcuklarının (Capparis spp.) Kullanımının Fenolikler, Antioksidant Kapasite ve Biyoerişilebilirliğe Etkisi. Akademik Gıda, 18, 390-401.

Guardiola, S. ve Mach, N. (2014). Therapeutic potential of Hibiscus sabdariffa: A review of the scientific evidence. Medicina Intensiva, 61(5), 274-295.
Hopkins, A. L., Lamm, M. G., Funk, J. L. ve Ritenbaugh, C. (2013). Hibiscus sabdariffa L. in the treatment of hypertension and hyperlipidemia: A comprehensive review of animal and human studies. Fitoterapia, 85(1), 84-94.

Karataşoğlu, E., Demirel, E., Şahin, T., Berktaş, S. ve Çam, M. (2021). Kalorisi azaltılmış mor reyhan soğuk çayı üretimi. Harran Tarım ve Gida Bilimleri Dergisi, 25(2), 163-171.

Maciel, L. G., do Carmo, M. A. V., Azevedo, L., Daguer, H., Molognoni, L., de Almeida, M. M., ... Rosso, N. D. (2018). Hibiscus sabdariffa anthocyanins-rich extract: Chemical stability, in vitro antioxidant and antiproliferative activities. Food and Chemical Toxicology, 113, 187-197.

Moser, C., Jaqueline, P., Barboza, G., Amanda, J. ve Mizuta, G. (2021). Comparative studies on chemical stability , antioxidant and antimicrobial activity from hot and cold hibiscus ( Hibiscus sabdariffa L .) calyces tea infusions. Journal of Food Measurement and Characterization, 15(4), $3531-3538$.

Naji, A. (2018). İnstant Hibiskus Çay1 Üretimi. Erciyes Üniversitesi Fen Bilimleri Enstitüsü Yüksek Lisans Tezi, Kayseri.

Nguyen, Q. V. ve Chuyen, H. Van. (2020). Processing of Herbal Tea from Roselle (Hibiscus sabdari ff a L.): Effects of Drying Temperature and Brewing Conditions on Total Soluble Solid, Phenolic Content, Antioxidant Capacity and Sensory Quality. Beverages, 6, 2.

Özünlü, O., ve Ergezer, H. (2019). İnfüzyon Yöntemi Kullanılarak Kurutulmuş Enginar Çanak Yaprağı Katkılı Soğuk Yeşil Çay Üretimi. Akademik Gıda, 17(4), 458-467.

Roberta Re, Nicoletta Pellegrini, Anna Proteggente, Ananth Pannala, Min Yang, A. C. R.-E. (1999). Antioxidant activity applying an improved abts radical cation decolorization assay. Free Radical Biology \& Medicine, 26, 1231-1237.

Singleton, V. L. ve Rossi, J. A. (1965). Colorimetry of Total Phenolics with Phosphomolybdic-Phosphotungstic Acid Reagents. American Journal of Enology and Viticulture, 16(3), 144-158.

Viljoen M, Muller M, De Beer D, Joubert E (2017). Identification of broad-based sensory attributes driving consumer preference of ready-to-drink rooibos iced tea with increased aspalathin content. South African Journal Botany, 110:177183.

Zhishen, J., Mengcheng, T. ve Jianming, W. (1999). The determination of flavonoid contents in mulberry and their scavenging effects on superoxide radicals. Food Chemistry. 